\title{
Identity Formation in the New Testament
}

\section{Ed. by Bengt Holmberg and Mikael Winninge}

[Identitätsbildung im Neuen Testament.]

Veröffentlicht auf Englisch.

Das frühe Christentum und die sich daraus entwickelnde Lebensform kann man am besten verstehen, wenn die Identität dieser Bewegung untersucht wird. Diese besteht nicht nur aus der eigenen Auffassung ihres Selbstverständnisses. Sie ist vielmehr eine komplexe Realität, die sich aus kognitiven, rituellen und moralischen Dimensionen zusammensetzt, die dann ihrerseits in den sozialen Beziehungen und Institutionen eine feste Form annehmen. Die Beiträger dieses Bandes verwenden dazu verschiedene Interpretationsansätze. Sie untersuchen die Intertextualität und Techniken der Identitätsbildung in den Texten, soziale Erkenntnistheorie und Geschlechterforschung zusammen mit postkolonialer Kritik an den Machtrelationen in frühchristlichen Texten.

Inhaltsübersicht

The Role of Biblical Traditions in Identity Formation

Samuel Byrskog: Christology and Identity in Intertextual Perspective. The Glory of Adam in the Narrative Substructure of Paul's Letter to the Romans - Per Jarle Bekken: The Controversy on Self-Witness according to John 5:31-40; 8:12-20 and Philo, Legum Allegoriae 3.205-208 - Tobias Hägerland: Rituals of (Ex-)Communication and Identity: 1 Cor 5 and 4Q266 11;4Q270 7 Identity Construction in texts Judith Lieu: Literary Strategies of Personification - Lauri Thurén: The Antagonists. Rhetorically Marginalized Identities in the New Testament - Thomas Kazen: Son of Man and Early Christian Identity Formation - Raimo Hakola: Social Identity and a Stereotype in the Making. Pharisees as Hypocrites in Matthew 23 - Rikard Roitto: Act as a Christbeliever, as a Household Member or Both? A Cognitive Perspective on the Relation Between the Social Identity in Christ and Household Identities in Pauline and Deutero-Pauline Texts

Gender-analytical Perspectives

Halvor Moxnes: Body, Gender, and Social Space. Dilemmas in Constructing Early Christian Identities - Fredrik Ivarsson: A Man Has To Do What A Man Has To Do. Protocols of Masculine Sexual Behaviour and 1 Corinthians 5-7 - Hanna Stenström: Masculine or Feminine? Male Virgins in Joseph and Aseneth and The Book of Revelation Postcolonial Analyses

Hans Leander: The Parousia as Medicine. A Postcolonial Perspective on Mark and Christian Identity Construction - Christina Petterson: Mission of Christ and Local Communities in Acts - Anna Rebecca Solevåg: Perpetua and Felicitas. Reinterpreting Empire, Family and Sexuality

Bengt Holmberg is professor emeritus at Lund University, Sweden.

Mikael Winninge is senior lecturer at Umeå University, Sweden.

Jetzt bestellen:

https://mohrsiebeck.com/buch/identity-formation-in-the-new-testament-9783161515163?no_cache=1 order@mohrsiebeck.com

Telefon: $+49(0) 7071-923-17$

Telefax: $+49(0) 7071-51104$ 